\title{
Autologous Conditioning
}

National Cancer Institute

\section{Source}

National Cancer Institute. Autologous Conditioning. NCI Thesaurus. Code C107096.

A preparative treatment regimen given prior to autologous cell transplantation. The regimen consists of chemotherapy with or without radiation and is intended to kill cancerous cells before the transplantation. 